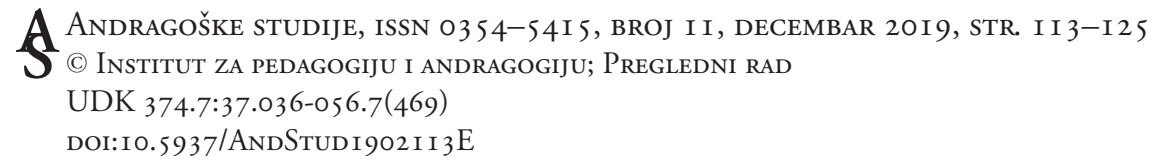

Teresa Eça ${ }^{1}$, Raquel Balsa ${ }^{2}$

Associação de Professores de Expressão e Comunicação Visual

\title{
Participatory Arts Projects: A Third Space for Companionship
}

\begin{abstract}
The paper focuses on educational art practices involving adults with disabilities. The introduction elaborates on two issues - the critical views of visual stereotypes and the negative representation of persons with disabilities in the media, and the arts as a means to give visibility to the hidden voices of people with disabilities. The second part of the article opens with a brief overview of research having to do with the fields of art education and disability studies, followed by the description and discussion of findings during a project funded by the European Community "CIRCLE OF COMPETENCES FOR COMMUNITY WORK WITH ADULTS”, implemented by the Art Teacher Association APECV and taking place in Portugal throughout 2018-2019. The APECV research team works both in formal and non-formal education contexts and develops participatory art education projects with other associations working with adults with intellectual disabilities.
\end{abstract}

Keywords: art education, adult education, community arts

\section{Visual Representation of the Other}

Some representations of disability, especially of mental illness, have been sadly disseminated, promulgating negative images of affected persons, and such portrayals significantly contribute to the detrimental effects of stigmatization promoting fear of the other. According to Jennifer Eisenhauer Richardson, this reflects a desire to control mental illness and protect the boundaries of presumed normality. Collective representation of mental illness is comprised of reiterating images and stereotypical ideas that can be identified in $16^{\text {th }}$ century artworks, as well as contemporary popular culture (Eisenhauer, 2008, p. 14). The manner in which society

1 Teresa Eca is a founder and a president of APECV (Associação de Professores de Expressão e Comunicação Visual), Portugal (teresatorreseca@gmail.com).

${ }^{2}$ Raquel Balsa is a communication designer and an associate of APECV (Associação de Professores de Expressão e Comunicação Visual), Portugal (raquelbalsa@gmail.com). 
treats persons with disabilities can also be traced throughout art history, as Michel Foucault (1988/1965) pointed out in Hieronymus Bosch's painting Ship of Fools, or as "otherness" or a strange being in a closed institution or asylum, such as in Hogarth's series of engravings (1735/1763). As Foucault (1988/1965) described, "madness had become a thing to look at: no longer a monster inside oneself, but an animal with strange mechanisms, a bestiality from which man had long since been suppressed" (p. 70). In the $18^{\text {th }}$ century, writers searched for visual ways to categorize illness they had difficulty understanding or accepting. Lavater's publication "Essays on Physiognomy" was one example of such illustrated publications. With another type and style of representation, artist Theodore Gericault created impressive portraits of 10 patients at La Salpêtrière in the period 1821-1824. Being a great painter, in those portraits Gericault was able to capture a great sense of humanity and despair, almost a gesture of love. In the era of photographic media, medical illustration used photography to try to capture the physical traits that identified different mental illnesses, as seen in the photographs of Hugh Diamond, who took pictures of his patients in the 1850s at the Surrey County Lunatic Asylum in Springfield, England or Jean-Martin Charcot photographs of women diagnosed with hysteria at La Salpêtrière in Paris, France. The visual culture of media promotes and produces a negative portrayal of mental illness, encouraging rejection of such a type of otherness. As pointed out by Lawson \& Fouts (2004) in their study on Disney characters: "These references were commonly employed to segregate, alienate, and denote the inferior status of the character(s) to which they referred" (p. 312). The representation of others often influences the way we see and accept the other, i.e. we cannot accept or cherish someone who is visually represented in a negative way in the media. Perhaps a crucial step for inclusion is the question of visual representation of those who are often depicted in the margins of the "norms". In the words of Jennifer Eisenhauer Richardson: "Art education can become an important site through which to challenge the issues of stereotypes, prejudice, and discrimination" (Eisenhauer, 2008, p. 17). She recommends art educators to foster a process of critical reflection about historical and contemporary representations of "normality" and mental illness to defy the maintenance and perpetuation of the stereotypes of illness.

\section{Representations of Self}

In the $19^{\text {th }}$ century, art was recognized as a diagnostic tool for determining nonfunctionality and psychopathology (Derby, 2011, p. 95). However, drawings produced by people diagnosed with disabilities were also a study subject for artists, 
not at all for medical purposes, but for their aesthetic qualities. $20^{\text {th }}$ century artists such as Jean Dubuffet and others from the Art Brut movement were the first ones to value visual works of art created by people diagnosed with mental illness.

The exhibition "La Folie en tête" held from November 2017 to March 2018 at the Maison de Victor Hugo, in Paris, displayed the works of artists suffering from mental illness, collected by psychiatrists interested in the boundary between art and therapy. The curators selected four collections: Dr. Browne collection (Crichton Royal Hospital in Scotland), Dr. Auguste Marie collection (Asylum of Villejuif, France); Walter Morgenthaler collection (Asylum of Waldau in Switzerland), and the Prinzhorn collection from the Hospital of the University of Heidelberg in Germany. The interest of the doctors in the art of their patients was the first step in giving visibility to the visual narratives of persons with disabilities. By providing spaces for artistic creation in hospitals, asylums, psychiatric clinics, the medical staff explored alternative ways to learn more about their patients and develop leisure activities that seemed to have positive results in some treatments. We will not discuss the aspects of initial arts therapy experiments that were further explored, since we are not specialists in the field. We will rather focus on the value of the works of art, the drawings, sculptures, embroideries, collages, etc. as representations of people living in the margins because of their mental or physical condition. Such genuine representations show intense, sensible personal feelings and accurate ways of seeing the world-hidden voices telling stories of life.

\section{Artists' Voices}

Let's stop here to examine the work of the Brazilian artist, Arthur Bispo do Rosário, born in Japaratuba, Sergipe, Brazil ca. 1910 and diagnosed with schizophrenia. He lived in a psychiatric institution in Rio de Janeiro for 50 years, where he created works of art with found objects. His works gained recognition among art critics when they were first displayed at the Venice Biennale in 1995. He never had access to artistic training, he joined the navy in 1925 and later worked as a boxer and handyman. Between 1933 and 1937, he worked in a trams company in the city of Rio de Janeiro and as a domestic worker. During the many years he lived in the psychiatric hospital, with the help of one of the doctors he had the opportunity to learn, experiment and explore visual art techniques, such as assemblage and embroidery. These conditions made the all difference. Of course there are other well-known artists who lived for long periods of time in psychiatric institutions, such as the Japanese artist Yayoi Kusama, born in 1929, trained at the Kyoto School of Arts and Crafts. But Arthur Bispo do Rosário was not 
an artist. He became one because someone in the hospital he lived in gave him the opportunity to express himself through art. His works are not appreciated because the author suffered from schizophrenia, but rather because of their high aesthetic quality. Like Arthur Bispo do Rosário, other people with mental illness can be excellent artists or craftsman if they have the opportunity to try and to produce works visible for others.

\section{Art Education and Disability Studies}

We understand that traditional terms used in education, such as Special Needs or Disability, encapsulate very strong meanings of rejection of the other when the other is different from the norm. Furthermore, the term inclusion, "with its multiple underlying ideologies and meanings, often obscures historical and problematic power relations" (Wexler, 2016, p. 37). However, we will use the term inclusion here as for the moment we cannot find a better one in literature, even if in as great majority of cases inclusive educational strategies exclude full participation in a system in which the people concerned have limited agency, as Alice Wexler described in her article "Re-imagining Inclusion/Exclusion" (Wexler, 2016).

"As a progressive field, art education must pay closer attention to

Disability Studies and other disability self-activism measures regarding Special Education. Art educators should strive toward innovative research that intersects the perspectives of disabled students, artists, and educators with Special Education as well as with intersecting identity issues. It is time for our field to acknowledge the dignity of disabled people and the validity of our way of being." (Derby, 2013, p. 380).

As in other fields of education, in formal and non-formal contexts, there is a growing interest in disability studies to test out strategies fostering social inclusion with vulnerable communities. In schools, we are challenged to revisit traditional ways of operationalizing the curriculum to find more flexibility and include students with disabilities recognizing their unique capacities. Communities are eager for more lifelong learning educational activities for participants who are often left out the cultural mainstream. But, it is not always without opposition. We are now able to criticize the language used in art therapy, and especially in special education, when talking about students with "special needs" as it discriminates the people designated with the "special needs" label (Derby, 2011). For Blandy, art education should have a socially transformative and reconstructive purpose (Blandy 1994, pp. $179 \& 181$ ). 
The congresses of the International Society of Education through Art InSEA devised a clear new direction towards the contribution of arts in inclusive educational projects. There is a considerable number of projects constructed by educational staff in museums, educators and teachers in schools, researchers in universities and artists and social workers in non-profit organizations. For example, Mimmu Rankanen's thesis found qualitative change in art, from cognitive control to spontaneous playful processing, which could be significant for aiding the transformation of previously painful experiences into ones that are emotionally manageable and for increasing resources for self-regulation (Rankanem, 2016). Ivona Mandic, an InSEA member from Croatia, in her visual essay for the journal IMAG \#1 described an interactive, educational exhibition to be perceived with several different senses (sight, touch, hearing, smell) aiming to integrate blind people into the cultural and social life of the community. The result of her study was a beautiful video ${ }^{3}$ illustrating non-visual ways of perceiving plastic art objects (Mandic, 2014). Such reflections point out a need to be sensitive to all kind of perceptions through the senses and not to rely only upon one of them. Visual, audio, and kinetic ways of perceiving are also ways of connecting people.

Mira Khalio-Tavin (2013) developed an artistic and art-educational collaborative project with a person with autism and an art pedagogue. In her study Mira explored the relationship with another developing theory through practice, raising a pedagogical encounter between the participants. Her position was not to define or know the other, but rather to learn from and with her/him. She argued that the notion of dialogical art pedagogy has to be redefined so as to be useful in diverse contexts, such as in disability contexts.

"We need to acknowledge the philosophical premises of pedagogy without trying to solve practical questions by aiming at creating certain dialogical conditions. Dialogue cannot be an aim itself because dialogue cannot be forced-it happens if it happens [...], much of the pedagogical confusion that educational philosophers are confronting takes place because these hidden significances, principles and acts are not recognised. It is the teacher's responsibility to recognise them in the "self", or at least to acknowledge that something like that exists in the "self" and in the "other". The difference between the two is that the "self" has no control over the "Other". So, the "self" can only influence its own actions and emotions." (Khalio-Tavin, 2013, p. 150).

\footnotetext{
${ }^{3}$ Ivona Biocic Mandic (2014) Sljepoća nije mrak, kratki film / Blindness is not darkness, short film. Retrieved from https://youtu.be/ZcgvQIsSvCA
} 


\section{A Third Space for Encountering the Other(s)}

From a participatory perspective, the arts offer diverse tools for engaging with the other. In the case of visual arts, where we have been experimenting with encounters and collective learning situations, dialogic spaces can be created, fostering development of knowledge and skills and allowing what Brent Wilson called a third space for relationships through imagination, affection, and being together in the margins (Wilson, 2008). And this "being together" no matter what happens is the third space. Sometimes, nothing happens, and that is just fine, because being together in the same space and in the same time is the beginning of communication. When we see the other taking the space to talk, to play a musical instrument over the table, to tell a story, to sing or to say nothing, that is just fine, because we are sharing a momentum, and it may be an artistic situation or by other words an art action. And, therefore, an art action can connect people.

\section{ASSOL and the Bindery}

There are institutions where disabled persons are engaged in artistic and crafts activities in a quiet atmosphere promoting a sense of usefulness. One of them is a charitable organization in Portugal called ASSOL. In ASSOL the caregivers use a methodology based on "gentle teaching", advocating for love and affection as being the best therapy. Gentle Teaching ${ }^{4}$ is an international partnership aimed at developing mentors and trainers according to its methods. Their focus is to strengthen companionship and community for all those they serve-children, adults and families that are struggling with mental illness, experiencing disability, homelessness, addictions and involvement with the criminal justice system. "Companionship is the cornerstone of a Gentle Teaching practice, creating meaningful, human connections between the person and the caregiver. The unconditional acceptance and gentle presence of this relationship establishes trust, and cultivates mutual learning and growing together" (Van de Siepkamp; McCrovitz; Vincent, 2018). A person learns about companionship through the caregiver's practice focus on safety, receiving and giving love and engagement.

We have been collaborating with the caregivers in ASSOL for many years, especially with Matias Pancho, the facilitator and creator of the bindery work-

\footnotetext{
${ }^{4}$ In this online article gentle teaching approach is explained: https://gentleteaching.com/ca/wp-content/ uploads/sites/2/2018/12/181002-De\%EF\%AC\%81ning-Gentle-Teaching.pdf
} 
shop $^{5}$. In our frequent visits to the bindery we observed a culture of hope through unconditional love and respect for one another. Many activities conducted in the institution help to find meanings together and create new memories through art practices fostering a sense of belonging. We have learned much with the caregivers in ASSOL. The first lesson was not to expect anything. Matias Pancho usually told us to be open to the results of the practice, whatever it might be. This is the consequence of unconditional love and respect for one another. Like Mira KhalioTavin said, dialogue cannot be an aim in itself because dialogue cannot be forced.

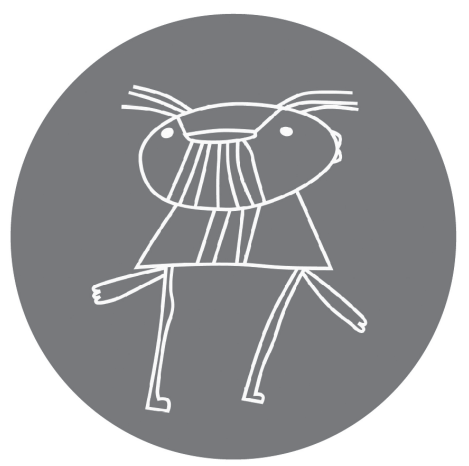

Picture 1: Cover of the Collaborative Books, by M. Simões

During the international project "Collaborative Books" activists from the group $\mathrm{C} 3^{6}$ invited people in the bindery to make books. They were eager to be engaged in new challenges in the bindery, they were curious about the books they created for the project, willing to know where and how the books were being distributed, they also created a collaborative book, being completely immersed as participants of the project. We asked Mr. Simóes, a participant of the bindery, to design the cover of the book series. Mr. Simóes is no longer able to produce art works, but his powerful images will be remembered by the more than 400 people who took part of the "Collaborative Books" project in the five continents of the world. With this first project with ASSOL, we realized the very essence of learning and collaborating through arts—it is not about changing the other, but a process of a mutual and interdependent development where artist, researcher,

\footnotetext{
${ }^{5}$ Movie from Matias Pancho about the book activities in ASSOL presented on 1st october at the Gentle Teaching International Conference 2018, in Breukelen, Netherlands: https://www.youtube.com/watch?v=xKahfbE7S0\&feature=youtu.be

${ }^{6} \mathrm{C} 3$ is a group of artists; teachers and researchers active in the field of art education. Web page: https://sharingsketchbooks.wordpress.com/c3/
} 
educator, and the caregivers take the first step inviting the others to engage in a relationship through creating art. Being engaged in various activities, like crafts or artworks, creates a sense of belonging to that community, increases self-esteem and different ways of connection with others. This may be a third space where adult education encounters community arts.

\section{Circle Project ${ }^{7}$}

In 2018-2019 we were involved in a project funded by the European Community "CIRCLE OF COMPETENCES FOR COMMUNITY WORK WITH ADULTS". The project was focused on the development of basic skills and key competences in adult learners through a system of actions which start from improving educators' competences and through them reach adult learners with fewer opportunities in the 4 partnering countries (Sicily-Italy, Slovenia, France and Portugal). Twenty educators from four countries with different professional profiles were engaged in collecting and sharing good practices and tools to facilitate and recognize their learners' achievements during 2018. Our organization decided to propose working with people with disabilities, and we invited ASSOL to collaborate with us. We also invited 6 facilitators to be trained in adult education. In order to prepare the workshops, we made a focus group interview with 8 persons from ASSOL (02-05-2018). The results of the interview showed that participants valued the following competencies in the facilitators: kindness, friendship, being a good (nice) person, and being:

$\square \quad$ Able to help;

$\square \quad$ Able to play;

$\square \quad$ Able to learn;

$\square \quad$ Attentive, mindful, observant, alert;

$\square \quad$ Knowledgeable;

$\square \quad$ Able to teach new things, make things;

$\square \quad$ Able to give feedback (correct the mistakes of the students);

It was interesting to note that for them companionship was so valued (eating together, playing together, learning together). We discussed the results of the interviews with the facilitators, so they could plan their workshops and be prepared to establish a good relationship with the group. The facilitators were

\footnotetext{
7 Project for Adult education funded by the European Community: Erasmus+ Key Action 2 Project: 2017-1-T02-KA204-036912. Avaliable at: https://cccwaproject.blog/apecv/ . Accessed 20-04-2019
} 
Pancho, who organized a workshop on binding books, Carlos, who organized a workshop on typography, Juliana, who organized a workshop on silk printing, Sergio, who organized a workshop on sound experimentation, Estrella, who organized a workshop on fanzines, and Mariana, who organized a workshop on making an e-portfolio.

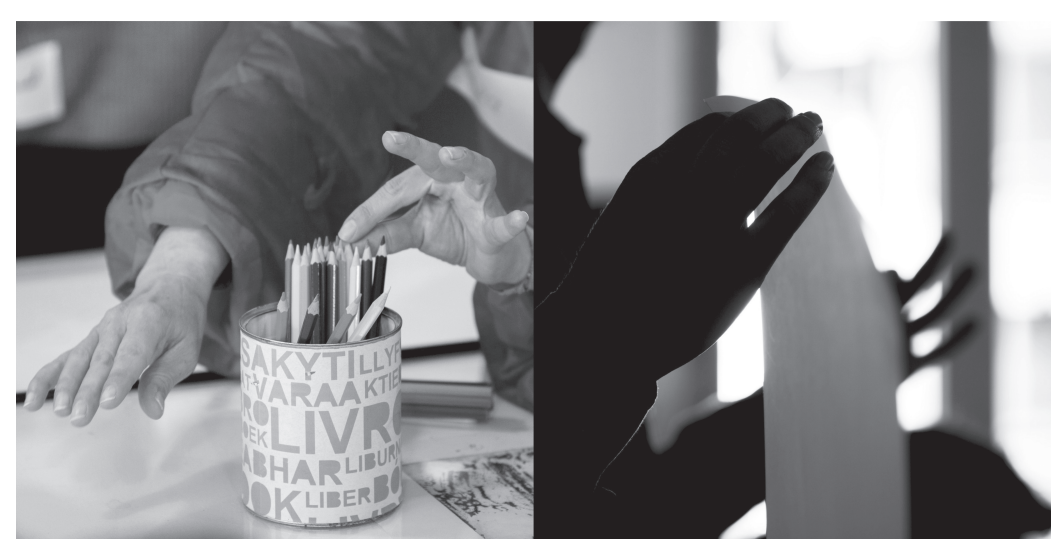

Picture 2: Circle: binding books (workshop with Matias Pancho)

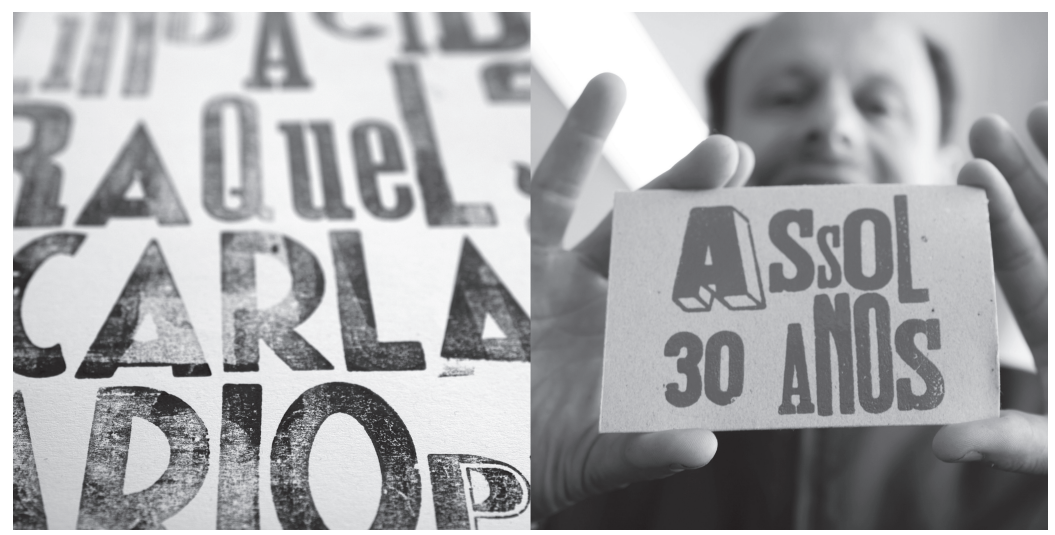

Picture 3: Circle: typography (workshop with Carlos) 


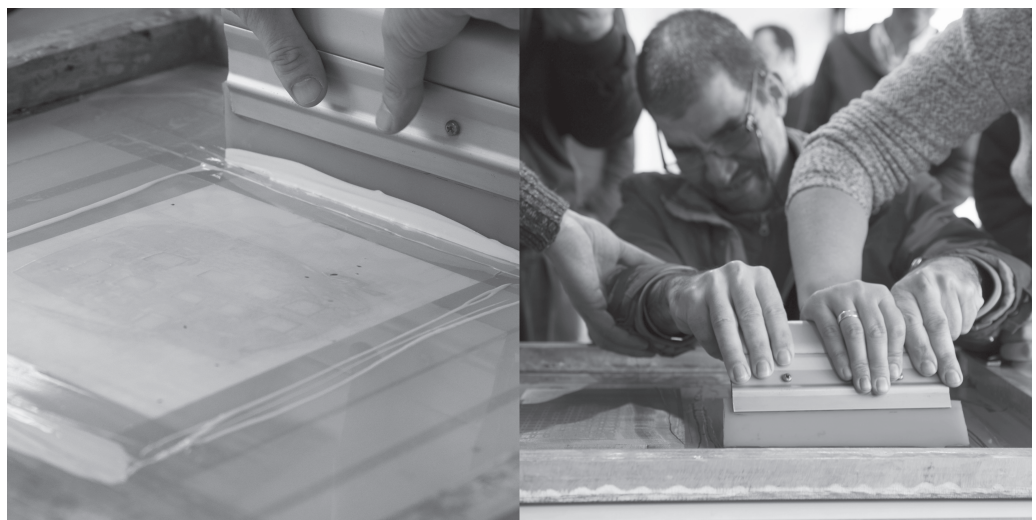

Picture 4: Circle: silk printing (workshop with Juliana)

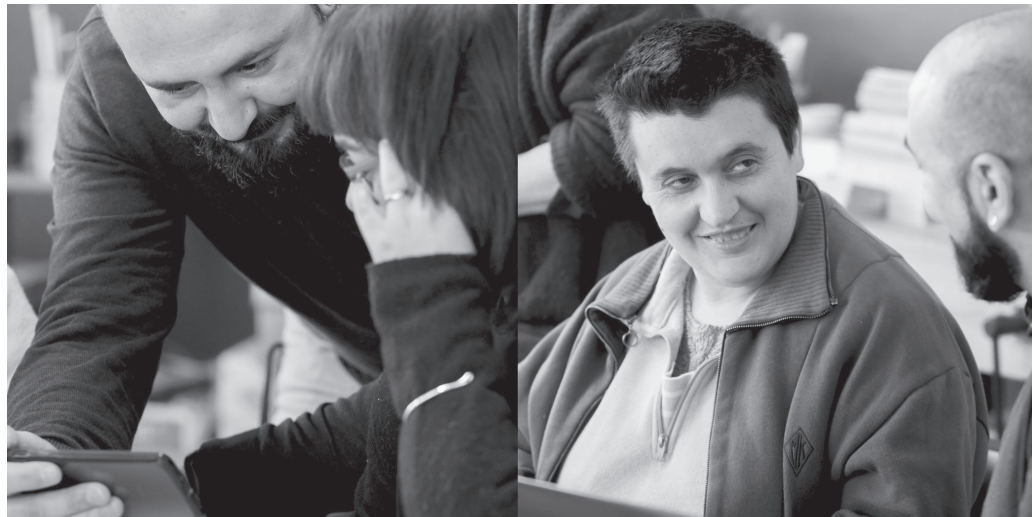

Picture 5: Circle: sound experimentation (workshop with Sergio)

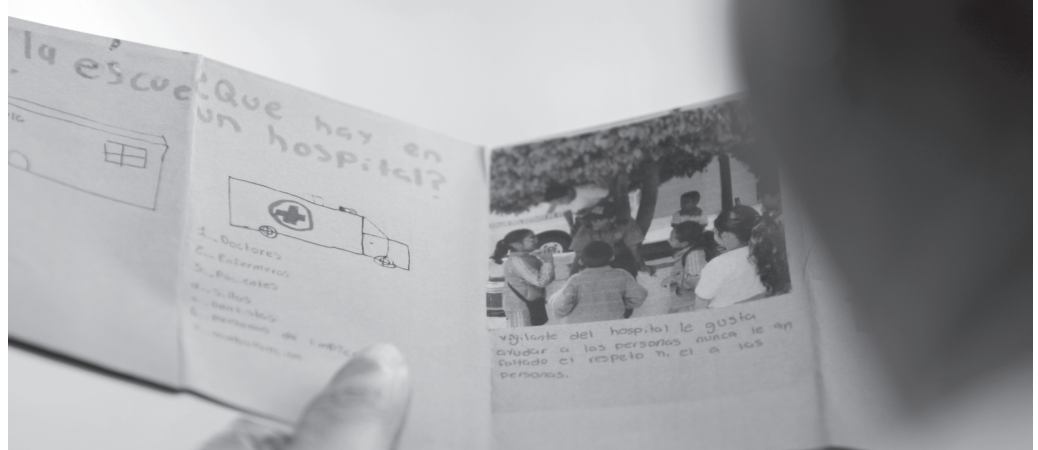

Picture 6: Circle: fanzine making (workshop with Estrella) 


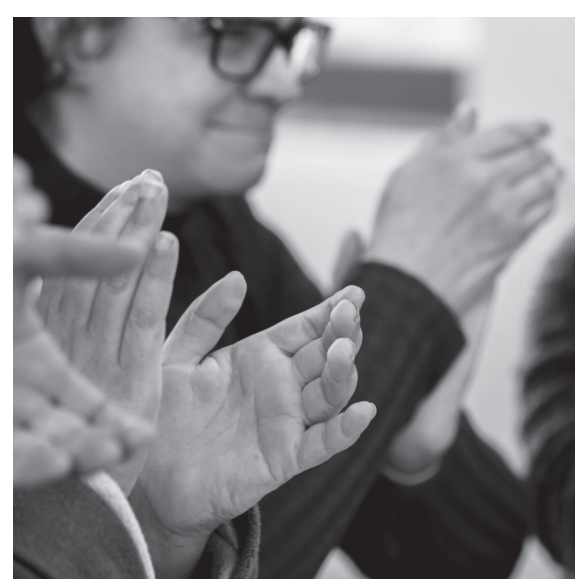

Picture 7: Circle: making an e-portfolio (workshop with Mariana)

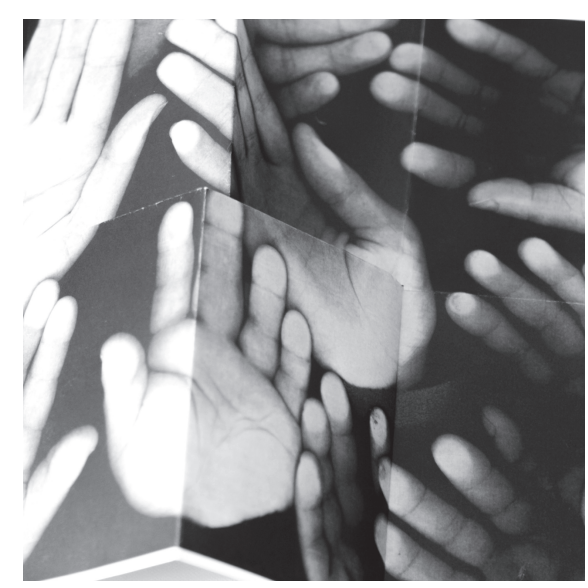

Figure 8: Assol Group representation

Two focus group interviews were conducted by two evaluators during the program-one after the $4^{\text {th }}$ workshop and the other after the last workshop, in order to evaluate the activities. According to the replies, there was great emphasis on the techniques and materials, as new things that have been learned and a sense of accomplishment in being able to produce the outcomes (binding a book, storytelling in the fanzine, printing their name using typography, printing one image on paper and textile, performing on music instruments, learning about digital photography, making a group webpage-e-portfolio).

We learned so much about being an artist, an educator and about ourselves during the Circle project, having discovered a third space where companionship was the key to interact with others. We have learned about respecting the rhythm of the group, being open to new situations, challenging our fears and ways of engagement through love. We were able to confirm that art practices offer valuable tools for engaging with the other, provoking encounters and creating safe relationships. As artists, we have perhaps never thought about the role of unconditional love for the other in an aesthetic relationship, and this is what working with disabled persons can teach artists and bring a new dimension to artistic workers. During the project, participatory research elements were sought—commitment to social change and empowerment of participants. We also looked for ways of guaranteeing participation of people with and without disabilities, allowing points of view to be balanced and thereby improving the rigor and scope of the research, as recommended by researchers from the field of disability studies (Fullana, Pallisera \& Villà, 2014, p. 724). 
In the Circle project, "To BE" gained a community dimension, the sense of acceptance of the other was nourished and the sense of belonging to a group was built. During the process between participants a space of potentialities was created, i.e. a unique place of sharing. This space of encounter provided by making art was a space of sharing and understanding, as Traquino pointed out talking about community art (Traquino, 2010) or as contemporary participatory art (Bishop, 2012). Working in transdisciplinary ways, between places and between people made us foresee the dynamic visions of work for an inclusive society-visions that pass through engagement and dialogue through artistic practices that unite us as a commitment to social change and empowerment of the participants. We were able to understand the need to enlarge the notion of a dialogical art pedagogy, as Mira Khalio-Tavin pointed out, embracing a dimension of companionship and love which is not always present.

\section{References}

Bishop, C. (2012). Artificial Hells: Participatory Art and the Politics of Spectatorship. London and New York: Verso Books.

Blandy, D. (1994). Assuming responsibility: Disability rights and the preparation of art educators. Studies in Art Education, 35(3), 179-187.

Derby, J. (2011). Disability studies and art education. Studies in Art Education, 52(2), $94-111$.

Derby, J. (2013). Nothing about us without us: Art Education's disservice to disabled people. Studies in Art Education, 54(4), 376-380.

Foucault, M. (1988). Madness and civilization: A history of insanity in the age of reason. New York: Kandom House, (original work published 1965).

Fullana, J., Pallisera, M., \& Vilà, M. (2014). Advancing towards inclusive social research: visual methods as opportunities for people with severe mental illness to participate in research. International Journal of Social Research Methodology, 17(6), 723-738.

Kallio-Tavin, M. (2013). Encountering SELF, OTHER AND THE THIRD: Researching the Crossroads of Art Pedagogy, Levinasian Ethics and Disability Studies. Aalto University. PhD Thesis.

Lawson, A., \& Fouts, G. (2004). Mental illness in Disney animated films. The Canadian Journal of Psychiatry, 49(5), 310-314.

Mandic, I. (2015). Blindness is not darkness, IMAG, 1(1). InSEA Publications.

Rankanen, M. (2016). The visible spectrum: participants' experiences of the process and impacts of art therapy. Helsinki: Aalto University.

EISEnhauer, J. (2008). A visual culture of stigma: Critically examining representations of mental illness. Art Education, 61(5), 13-18. 
Van de Siepkamp, P., McCrovitz, A. M., \& Vincent, M. (2018). Defining Gentle Teaching. Amsterdam: Gentle Teaching International. Retrieved from https://gentleteaching.com/ca/wp-content/uploads/sites/2/2018/12/181002De\%EF\%AC\%81ning-Gentle-Teaching.pdf

Wexler, A. J. (2016). Re-imagining inclusion/exclusion: Unpacking assumptions and contradictions in arts and special education from a critical disability studies perspective. Journal of Social Theory in Art Education, 36(1), 32-42.

Wilson, B. (2008). Research at the Margins of Schooling: Biographical Inquiry and ThirdSite Pedagogy. International Journal of Education through Art, 4(2), 119-130.

Teresa Eça ${ }^{8}$, Raquel Balsa9

Udruženje nastavnika ekspresije i vizuelne komunikacije

\section{Participativni umetnički projekti: treći prostor udruživanja}

Apstrakt: Ovaj rad analizira prakse umetničkog obrazovanja koje su namenjene odraslim osobama sa invaliditetom. U uvodu razmatramo dva aspekta: kritički osvrt na vizuelne stereotipe i negativno predstavljanje osoba sa invaliditetom u medijima, kao i ideju da umetnost može da ponudi prostor za ispoljavanje skrivenih kapaciteta osoba sa invaliditetom. Drugi deo rada počinje kratkim pregledom istraživanja iz područja umetničkog obrazovanja i studija invaliditeta, nakon čega slede opis i diskusija o saznanjima iz projekta Evropske zajednice „KRUG KOMPETENCIJA ZA RAD SA ODRASLIM OSOBAMA U ZAJEDNICI“ (eng. CIRCLE OF COMPETENCES FOR COMMUNITY WORK WITH ADULTS), koji je u periodu od 2018. do 2019. u Portugaliji realizovalo Udruženje nastavnika umetnosti APECV. Istraživački tim APECV deluje kako u formalnim, tako i u neformalnim kontekstima obrazovanja i razvija participativne projekte umetničkog obrazovanja sa drugim udruženjima koja sarađuju sa odraslim osobama sa intelektualnim smetnjama.

Ključne reči: umetničko obrazovanje, obrazovanje odraslih, umetnost u zajednici

\footnotetext{
8 Teresa Eca je osnivač i predsednik udruženja APECV (Associação de Professores de Expressão e Comunicação Visual) u Portugaliji (teresatorreseca@gmail.com).

9 Raquel Balsa je dizajner komunikacija i saradnik udruženja APECV (Associação de Professores de Expressâo e Comunicação Visual) u Portugaliji (raquelbalsa@gmail.com).
} 